Historic, Archive Document

Do not assume content reflects current scientific knowledge, policies, or practices. 


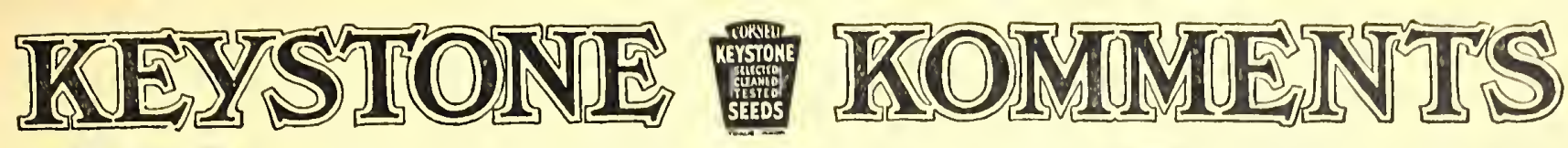

PUBLISHED IN THE INTEREST OF BETTER SEEDS

Vol. 7 No. 7

CORNELI SEED COMPANY, 230 BIDDLE STREET, ST LOUIS, MO.

Feb. 26

\section{KOREAN LESPEDEZA}

Korean lespedeza has proved itself well adapted to Missouri soils and seasons. During the past six years the Missouri College of Agriculture has studied the general usefulness of the legume in this State.

\section{Korean, Kobe and Common Lespedeza}

In recent years the Korean and the Kobe varieties of lespedeza have been introduced into Missouri. Common lespedeza, known also as Japan clover, has been native to the southern third of the State for many years,

natural pasturage on opention it furnishes the principal soil adaptations of the three varieties of lespedeza are apparently very similar. All appear to be tolerant to acid soils and will grow and reproduce on either fertile or poor land.

The three varieties differ, however, in the stage of maturity and the amount of growth developed during the season. In time required to mature the Korean is early, the Common is medium late, the Kobe extremely late. Korean will safely mature seed anywhere in Missouri. Common also will mature over a broad territory, but is much better adapted to the southern half of the State. Kobe will ripen regularly in the southern third. Korean is the mostly widely adapted variety when both yield and safe ripening of seed are considered.

\section{Growth Habits of Korean Lespedeza}

Korean lespedeza is an annual legume, coming each spring from the seed. Sown in that season on wheat or with oats, sown alone or sown on pasture land, it starts growth during the first mild days in April. It progresses rapidly with continued warm weather, and reaches full stature about the middle of June, which is maintained through July and August when native pastures are at their lowest stage. An abundance of seed is produced, whether the crop has been cut for hay or pastured, to reseed naturally a full stand the following spring. Ripening is complete by the time of the first light frosts in September. Where the stand is thin or sown in rows the plants are prostrate in growth, developing trailing habits. In a thick stand, however, the growth is upright, similar to that of red clover or alfalfa.

Korean lespedeza is generally adapted to all soils. It is known to grow well on acid soil, though it has not seemed to thrive vigorously on land that is extremely flat and poorly drained. Yields of the crop respond to the relative fertility of the soil. On moderately fertile land a growth equal to that from the first cutting of good red clover may be obtained. On poor soils there is likely to be a considerable growth every year for grazing, but only the most favorable seasons will produce there a growth tall enough to cut for hay.

\section{Not a Competitor of Red or Sweet Clover}

Korean lespedeza is not directly competitive with red clover or sweet clover. On the more productive land either of the latter varieties will make greater returns in hay or pasture and prove more beneficial to the soil.

Sweet clover, however, on land medium to low in fertility will not usually grow without expensive soil treatments. Red clover on such soils will grow only fairly well, and if the land is both poor and sour, costly treatments are usually necessary for successful production.

Whether the farmer should go to the expenes of growing red or sweet clover, or should use Korean lespedeza as a substitute, can be determined only after considering the conditions of the individual case.
Korean lespedeza can be grown to advantage on many soils where production of the clovers is difficult or impracticable. It may be sown in small grain crops, in grass-clover mixtures for temporary or permanent pasture, or on idle and waste land not now affording any profits and yearly becoming less valuable.

\section{Method and Time of Seeding}

Korean lespedeza is best sown in the spring during late March or early April. It may be sown with oats immediately after the seed grain has been covered, or

Korean lespedeza establishes itself more quickly where the ground is firm and well packed. For that reason it is more likely to succeed and make a larger growth the first season if sown on wheat rather than with oats.

The seed is not difficult to sow and may be distributed by a grass-clover seeder, by a wheelbarrow seeder, or by a grass-clover attachment on a grain drill.

\section{Rates of Seeding}

From 5 to 10 pounds of seed to the acre should be sown where a full growth is desired that season, whether the crop is seeded alone or seeded with wheat or oats. Korean lespedeza apparently is resistant to early spring freezees. Observations on the Experiment Station field at Columbia indicate that late freezing weather is more likely to injure young red clover or alfalfa than lespedeza. It is certain that lespedeza may be sown early in the spring with no great danger of losing the stand. There is, however, no special advantage in seeding extremely early, since the crop does not grow rapidly until warm weather.

\section{Pasturing Korean Lespedeza}

The growth of lespedeza starts slowly in the spring and does not progress rapidly until early summer. Grazing may begin by the middle of June and be continued through to frost in September, depending upon the size of the growth and rate of its use. In dry weather light grazing from early June onward will often give greater returns for the season than delaying the use of the pasture until July. This is especially true if the stand is very thick. Grazing when the ground is watersoaked will injure both the stand and the soil.

\section{Korean Lespedeza in Permanent Pastures}

Korean lespedeza is a valuable legume to sow in permanent pastures of blue grass, of red top, of orchard grass, or of mixed grasses. Its habits of growth and high nutritive quality makes it especially suitable for mixtures with other pasture plants. In July and August when native grass is short, the lespedeza makes its greatest growth, providing good pastureage through the dry summer months. By the middle of September its growth declines from maturity, giving way for the growth of grasses following rain in early fall.

\section{Korean Lespedeza for $\mathrm{Hay}$}

Korean lespedeza is less suitable for hay than for pasturage. If this legume is sown for hay on land of sufficient fertility to grow good crops of red clover, its returns are not likely to be as satisfactory as those from red clover. Red clover will make greater yields of hay during the season. It will start earlier in the spring, and its growth is more beneficial to the soil. In other words, on productive soils where Korean clover can be expected to make consistent yields of hay, red clover is preferable for the same purpose. 



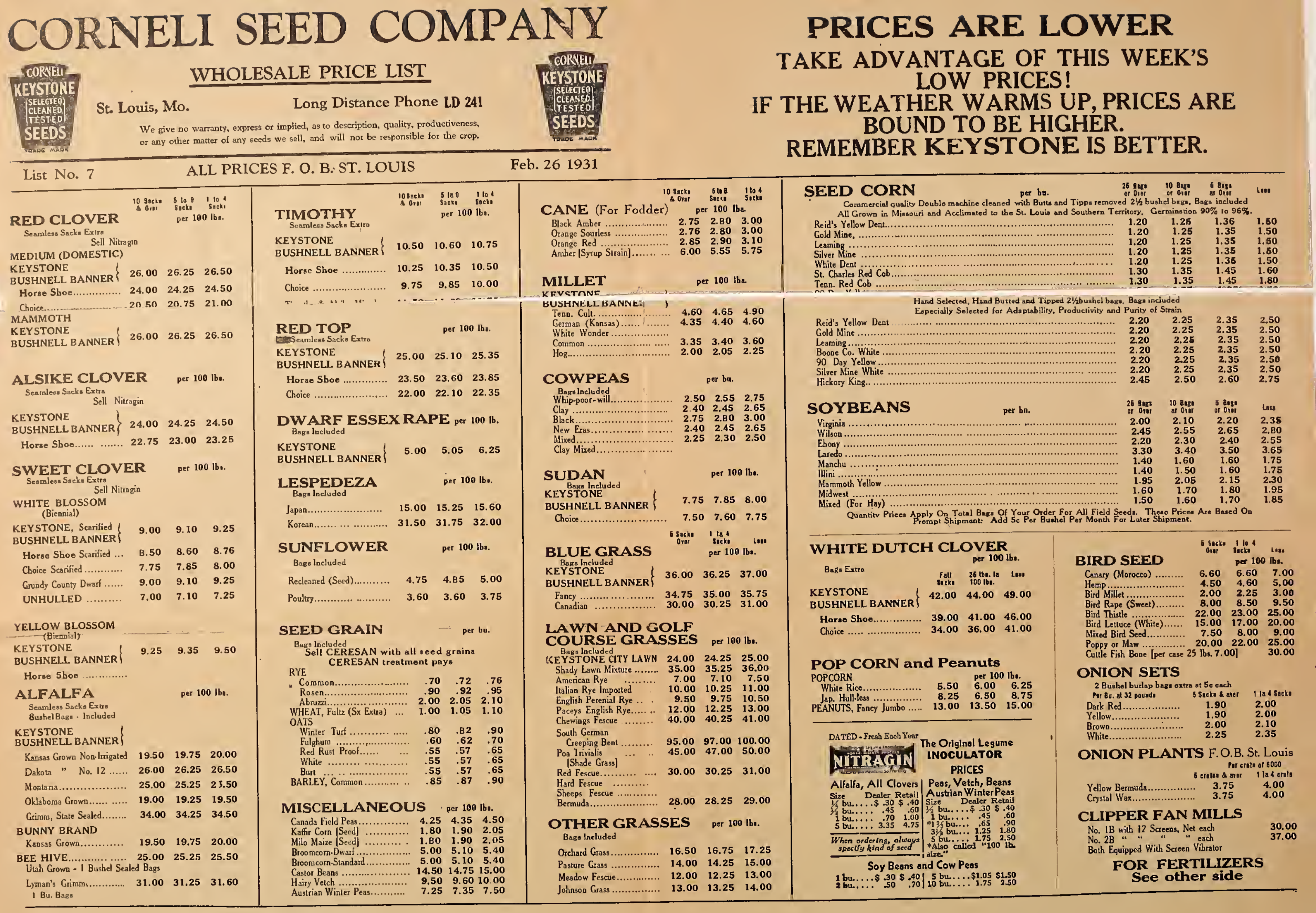


SEMESAN

A General Disinfectant for Vegetable and Flower Seeds or Bulbs, and Certain Plant Diseases.

\begin{tabular}{|c|c|c|c|}
\hline $\begin{array}{l}\text { Sizes of } \\
\text { Packages }\end{array}$ & $\begin{array}{c}\text { Retail } \\
\text { Prico } \\
\text { Per } \\
\text { Pleg. } \\
\end{array}$ & $\begin{array}{l}\text { Dealer } \\
\text { Price }\end{array}$ & $\begin{array}{c}\text { Plegs. } \\
P_{\text {Bt }} \\
\text { Case }\end{array}$ \\
\hline $\begin{array}{l}\text { 2-oz. tin } \\
\text { 1-lb. " " } \\
\text { 5-lb. " } \\
\text { 26-lb. pail } \\
\text { 100-lb. drum } \\
\text { 300-lb. " }\end{array}$ & $\begin{array}{r}5.50 \\
2.75 \\
13.00 \\
56.25 \\
220.00 \\
645.00\end{array}$ & 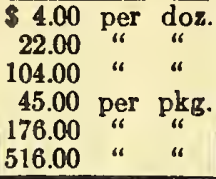 & $\begin{array}{cc}3 & \text { doz. } \\
2 & \text { " } \\
1 / 2 & \text { " } \\
1 & \text { only } \\
1 & \text { " } \\
1 & \text { “ }\end{array}$ \\
\hline
\end{tabular}

SEMESAN JR.

A Dust Disinfectant for Seed Corn.

\begin{tabular}{|c|c|c|c|}
\hline $\begin{array}{l}\text { Sizes of } \\
\text { Packages }\end{array}$ & $\begin{array}{c}\text { Retail } \\
\text { Price } \\
\text { Per } \\
\text { Plg. }\end{array}$ & $\begin{array}{l}\text { Dealer } \\
\text { Price }\end{array}$ & $\begin{array}{c}\text { Pkgs. } \\
\text { Per } \\
\text { Case }\end{array}$ \\
\hline $\begin{array}{l}\text { 4-oz. tin } \\
\text { 1-lb. " } \\
5 \text {-lb. " } \\
\text { 25-lb. pail } \\
100-\text { lb. drum } \\
\text { 300-lb. " }\end{array}$ & $\begin{array}{r}550 \\
1.76 \\
8.00 \\
31.25 \\
120.00 \\
345.00\end{array}$ & $\begin{array}{r}4.00 \text { per doz. } \\
14.00 \text { " } \\
64.00 \text { " } \\
25.00 \text { per pkg. } \\
96.00 \text { " } \\
276.00 \text { " } \\
6\end{array}$ & $\begin{aligned} 3 & \text { doz. } \\
2 & \text { " } \\
1 / 2 & \text { " } \\
1 & \text { only } \\
1 & \text { " } \\
1 & \text { " }\end{aligned}$ \\
\hline
\end{tabular}

RETURN POSTAGE GUARANTEED

CORNELI SEED COMPANY

Garden, Field, Grass Seeds $\mathcal{Z}$ Onion Sets

Saint Louis, U. S. A.
NEW IMPROVED

SEMESAIN BEL

An Instantaneous Dip Disinfectant for Seed Potatoes

\begin{tabular}{|c|c|c|c|}
\hline $\begin{array}{l}\text { Sires of } \\
\text { Packages }\end{array}$ & $\begin{array}{c}\text { Retail } \\
\text { Price } \\
\text { Per } \\
\text { Package }\end{array}$ & $\begin{array}{l}\text { Dealer } \\
\text { Price }\end{array}$ & $\begin{array}{l}\text { Pachages } \\
\text { Per Cave }\end{array}$ \\
\hline $\begin{array}{l}\text { 4-oz. tin } \\
\text { 1-1b. "“ } \\
\text { 5-1b. “c } \\
25-1 b . \text { pail } \\
100-\text {-b. drum } \\
\text { 300-lb. }\end{array}$ & $\begin{array}{r}\$ .50 \\
1.75 \\
8.00 \\
31.25 \\
1200 \\
345.00\end{array}$ & 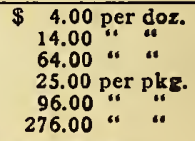 & 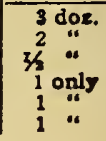 \\
\hline
\end{tabular}

\section{CERESAN}

A Dust Disinfectant for Wheat, Oats, Barley, other Cereals and Cotton

SEED

DISINFECTANTS

\begin{tabular}{|c|c|c|c|}
\hline $\begin{array}{l}\text { Sizes of } \\
\text { Packages }\end{array}$ & $\begin{array}{c}\text { Retail } \\
\text { Price } \\
\text { Per } \\
\text { Pkg. }\end{array}$ & $\begin{array}{l}\text { Dealer } \\
\text { Price }\end{array}$ & $\begin{array}{l}\text { Pkgs. } \\
\text { Per } \\
\text { Case }\end{array}$ \\
\hline $\begin{array}{l}\text { 8-oz. tin } \\
1-1 \mathrm{lb} . " “ \\
5 \text {-lb. “ }\end{array}$ & \begin{tabular}{rr|} 
& 50 \\
.75 \\
3.00
\end{tabular} & $\begin{array}{r}\$ 4.00 \text { per doz. } \\
6.00 \text { " " } \\
24.00 \text { " }\end{array}$ & $\begin{array}{l}3 \text { doz. } \\
2 \text { "“ } \\
1 / 2\end{array}$ \\
\hline $\begin{array}{l}25-\text { lb. pail } \\
00-\text { lb. drum } \\
00 \text {-lb. }\end{array}$ & $\begin{array}{r}12.50 \\
49.00 \\
144.00\end{array}$ & $\begin{array}{r}10.00 \text { per pkg. } \\
39.20 \text { " } \\
115.20\end{array}$ & $\begin{array}{ll}1 & \text { only } \\
1 & 1 \\
1 & 4\end{array}$ \\
\hline
\end{tabular}

U. S. Dept. of Agric.

Washington, I. C.

Sec. 4351/2 P. L. E R

U. S. POSTAGE

\section{PAID}

St. Louis, Mo.

Permit 336

\section{MARKET QUOTATIONS}

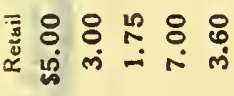

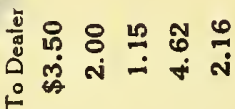

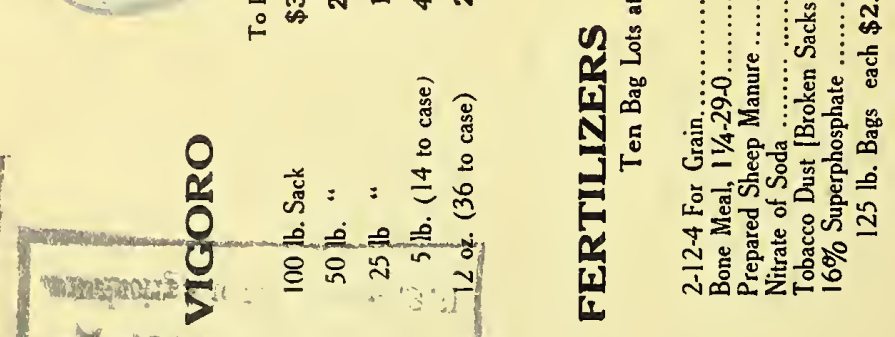

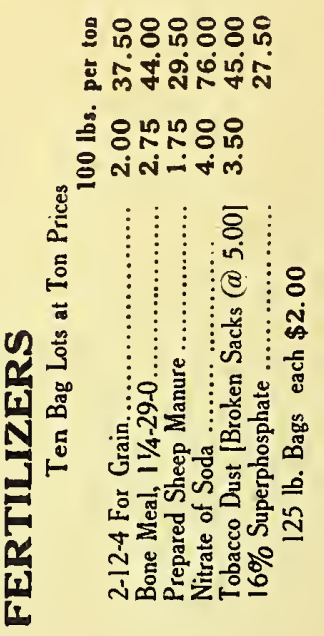

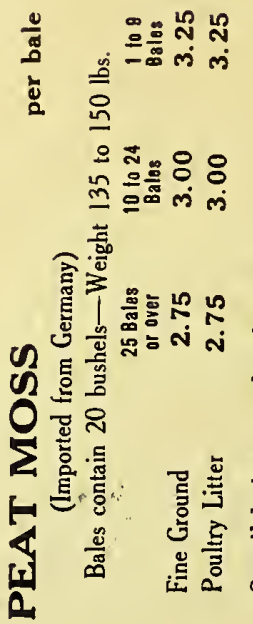

$\infty$

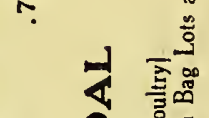

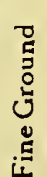

